\title{
PENGEMBANGAN EKONOMI KREATIF DESA MELALUI BADA USAHA MILIK DESA (BUMDES) MENUJU KOPERASI BERBASIS IT
}

\section{Hendro Wibowo ${ }^{凶}$}

Sekolah Tinggi Ilmu Fikih (STIF) Syeikh Nawawi Tanara Serang Banten - Indonesia

\begin{abstract}
Abstrak
Alokasi Dana Desa (Dana Desa) dari tahun ke tahun mengalami peningkatan, Pemerintah Pusat telah mengalokasikan Dana Desa pada tahun 2015 sebesar Rp 20 triliun dan pada tahun 2016 meningkat menjadi Rp 47 triliun dan pada tahun 2017 meningkat menjadi Rp 60 triliun. Untuk Provinsi Banten pada tahun 2015 telah menerima dana desa sebesar Rp 200 miliar, pada tahun 2016 meningkat menjadi Rp 791 miliar dan pada tahun 2017 menjadi Rp 1 triliun. Dengan adanya Dana Desa diperlukan akuntabilitas pengelolaan keuangan desa dalam hal perencanaan, pelaksanaan, penatausahaan, pelaporan, pertanggungjawaban, pembinaan dan pengawasan keuangan desa serta untuk mengetahui pertanggungjawaban pengelolaan keuangan desa. Tujuan kedepan alokasi Dana Desa dari Pemerintah Pusat dalam rangka membentuk Badan Usaha Milik Desa. Penelitian ini bertujuan untuk mengembangkan alokasi Dana Desa yang dapat dialokasikan dalam pembuatan Badan Usaha Milik Desa yang berbadan hukum Koperasi dengan mengembangkan potensi Ekonomi Desa yang ada berbasis Teknologi menggunakan Teknologi Sistem Keuangan dan Market Place.
\end{abstract}

Kata Kunci: Alokasi Dana Desa (ADD), BUMDes, Fintech dan Market Place 


\begin{abstract}
The allocation of Village Funds (Dana Desa) from year to year increased, the Central Government has allocated Village Funds in 2015 amounting to Rp 20 trillion and in 2016 increased to $R p 47$ trillion and in 2017 increased to $R p 60$ trillion. For the province of Banten in 2015 has received village funds amounting to $R p 200$ billion, in 2016 increased to $R p 791$ billion and in 2017 to $R p 1$ trillion. With the Village Fund is required accountability of village financial management in terms of planning, implementation, administration, reporting, accountability, guidance and supervision of village finances and to know the accountability of village financial management. The future goal of the allocation of Village Funds from the Central Government in order to form a Village Owned Enterprise (Badan Usaha Milik Desa). This study aims to develop the allocation of Village Funds can be allocated in the manufacture of Village Owned Enterprises with legal status of Koperasi by developing the potential of existing Village Economics based on Technology using Financial System Technologi and Market Place.
\end{abstract}

Keywords: Alokasi Dana Desa (ADD), BUMDes, Fintech dan Market Place

Copyright (c) 2021 Hendro Wibowo.

$\triangle$ Corresponding author: Hendro Wibowo

Email Address : hendro.wibowo83@gmail.com

\title{
PENDAHULUAN
}

\section{A. Latar Belakang}

Indonesia merupakan negara dengan jumlah penduduk terbesar didunia ke-4 dengan jumlah 252,20 juta jiwa (BPS, 2015). Dari Ditjen Kependudukan dan Pencatatan Sipil Kemendagri per semester II bulan Desember tahun 2014 menunjukkan bahwa penduduk tersebar di 74.754 desa (Kemendagri, 2015). Pada tahun 2010, persentase penduduk yang bertempat tinggaldi perdesaan sebesar 50,2 persen dan pada tahun 2015 diperkirakan semakin berkurang menjadi 46,7 persen (BPS, 2014). Jumlah penduduk miskin pada Maret 2016 sebanyak 28,01 juta orang atau 10,86 persen dari jumlah penduduk. Adapun jumlah penduduk miskin terbanyak di daerah perdesaan dengan jumlah 17,67 juta orang atau 63,08 persen dari seluruh penduduk miskin (BPS, 2016).

Berdasarkan Pasal 23 ayat 1 UUD 1945, pendanaan pembangunan dan alokasi APBN senantiasa ditunjukan untuk mewujudkan kesejahteraan rakyat. Guna mendukung pemerataan pembangunan, APBN tahun 2014 telah mengalokasikan Dana Transfer Daerah sebesar Rp.592,6 triliun atau 5,7 persen dari PDB, yang dirinci 82,3 persen berupa Dana Perimbangan dan 17,7 persen berupa Dana Otonomi Khusus dan Penyesuaian. Jumlah tersebut meningkat 10,7 persen jika dibandingkan dengan pagu dalam APBNP 2013 sebesar Rp. 529,4 triliun (Kementerian Keuangan, 2014).

Tabel 1. 1 Jumlah Penduduk Indonesia

\begin{tabular}{|c|l|l|}
\hline No & \multicolumn{1}{|c|}{ Kriteria } & \multicolumn{1}{|c|}{ Jumlah } \\
\hline 1. & $\begin{array}{l}\text { Jumlah Penduduk Tahun } \\
2015\end{array}$ & 252,20 juta jiwa \\
\hline 2. & $\begin{array}{l}\text { Persentase Penduduk } \\
\text { Perdesaan Tahun 2010 }\end{array}$ & 50,2 persen \\
\hline
\end{tabular}




\begin{tabular}{|c|l|l|}
\hline No & \multicolumn{1}{|c|}{ Kriteria } & \multicolumn{1}{|c|}{ Jumlah } \\
\hline 3. & $\begin{array}{l}\text { Jumlah Penduduk Miskin } \\
\text { (Maret 2016) }\end{array}$ & $\begin{array}{l}\text { 28,01 juta jiwa (10,86 persen dari } \\
\text { jumlah penduduk) }\end{array}$ \\
\hline 4. & $\begin{array}{l}\text { Jumlah Penduduk Miskin } \\
\text { Perdesaan }\end{array}$ & $\begin{array}{l}\text { 17,67 juta jiwa (63,08 persen dari } \\
\text { seluruh penduduk miskin) }\end{array}$ \\
\hline 5. & Jumlah Desa & 74.754 desa \\
\hline
\end{tabular}

Sumber: BPS 2014, 2015, 2016, Kemendagri 2015 dan data diolah 2017

Pelaksanaan keuangan daerah masih menghadapi permasalahan rendahnya kualitas belanja daerah. Selain itu, pelaksanaan Anggaran Pendapatan dan Belanja Daerah (APBD) masih menemui beberapa kendala, antara lain: masih banyaknya daerah yang terlambat menetapkan APBD, struktur APBD yang kurang ideal, struktur belanja daerah masih didominasi oleh belanja pegawai, minimnya belanja infrastruktur, dan tingginya penggunaan sisa lebih perhitungan (SiLPA) anggaran daerah dari tahun sebelumnya serta kendala administratif pengelolaan keuangan yang tercermin dari masih banyaknya daerah yang mendapat opini kurang baik dari Badan Pemeriksa Keuangan/ BPK (Kementerian Keuangan, 2014).

Masyarakat di daerah, khususnya di wilayah perdesaan, masih menghadapi keterbelakangan, kemiskinan, dan kesulitan dalam mengakses pelayanan publik. Kondisi ini mendorong kesadaran perlunya pemerataan pembangunan dan dukungan keuangan publik (APBN) bagi masyarakat desa. Alokasi APBN bagi desa diharapkan dapat menarik keterlibatan masyarakat dalam pembangunan (Abidin, 2015).

Dalam rangka menciptakan landasan yang kuat dalam melaksanakan pembangunan desa, pemerintah dan DPR RI telah menerbitkan UU NO. 6 Tahun 2014 tentang Desa. Salah satu pasalnya dijelaskan bahwa desa memiliki kewenangan dalam bidang penyelenggaraan pemerintahan, pembangunan, pembinaan kemasyarakatan dan pemberdayaan desa (Fajri, Setyowati, \& Siswidiyanto, n.d.).

UU No. 6 Tahun 2014 tentang Desa mencantumkan pengaturan mengenai keuangan desa dan aset desa dalam Bab VIII Pasal 71 sampai dengan Pasal 77. Berkaitan dengan sumber pendapatan desa, Pasal 72 ayat 1 huruf $b$ menyebutkan bahwa sumber dana desa berasal dari alokasi Anggaran Pendapatan dan Belanja Negara. Selanjutnya, Pasal 72 ayat 2 menyatakan bahwa alokasi anggaran sebagaimana dimaksud pada ayat (1) huruf $b$ bersumber dari Belanja Pusat dengan mengefektifkan program yang berbasis desa secara merata dan berkeadilan. Penjelasan Pasal 72 menyebutkan alokasi dana desa dari APBN dilaksanakan dalam rangka meningkatkan kesejahteraan dan pemerataan pembangunan desa. Untuk memberikan pedoman lebih lanjut, Pemerintah menindaklanjuti kebijakan dana desa dengan menerbitkan PP No. 60 Tahun 2014 tentang Dana Desa Yang Bersumber Dari Anggaran Pendapatan dan Belanja Negara yang mengatur alokasi dana desa yang bersumber dari APBN yang berubah menjadi PP No. 22 Tahun 2015 (Abidin, 2015).

Sebelum berlaku UU No. 6 Tahun 2014 tentang Desa, pengelolaan keuangan desa didasarkan pada UU No. 32 Tahun 2004 tentang Pemerintahan Daerah dan merupakan bagian dari keuangan daerah. Merujuk pada permasalahan pengelolaan keuangan daerah yang disampaikan Kementerian Keuangan, pelaksanaan pengelolaan keuangan desa memunculkan keraguan. Berbagai permasalahan tersebut dapat menghambat pencapaian tujuan kebijakan dana desa, yaitu peningkatan kesejahteraan dan pemerataan pembangunan desa (Abidin, 2015). 
Dalam mempersiapkan implementasi UU Desa, setiap pemdes dituntut untuk mempersiapkan Anggaran Pendapatan dan Belanja Desa (APBDesa). Di sisi lain, pemdes justru belum dapat menghitung pendapatan asli desa yang akan dimasukkan dalam APBDesa. Selain keterbatasan waktu penyusunan APBDesa, kesulitan yang dihadapi Pemdes adalah sistem administrasi keuangan yang jauh berbeda dibandingkan sebelum adanya UU Desa. Serta pengelolaan anggaran secara mandiri oleh pemdes, termasuk didalamnya pengelolaan penghasilan bagi perangkat desa dan belanja publik dengan perbandingan 30\% untuk gaji perangkat desa serta $70 \%$ untuk pembangunan (Rahmawati, 2015).

Adapun rincian dana desa 2015 telah ditetapkan dalam Peraturan Presiden Republik Indonesia no. 36 tahun 2015 tentang rincian Anggaran Pendapatan dan Belanja Negara (APBN) tahun anggaran 2015, rincian dana desa menurut Kabupaten/ Kota menyebutkan total nasional dana desa sebesar 20,77 T. dan Dana desa terus mengalami peningkatan di tahun 2016, Peraturan Presiden Republik Indonesia no. 137 tahun 2015 tentang rincian Anggaran Pendapatan dan Belanja Negara (APBN) tahun anggaran 2016, rincian dana desa menurut Kabupaten/ Kota menyebutkan total nasional dana desa sebesar 47,10 $\mathrm{T}$. Hal ini meningkat menjadi 26,33 $\mathrm{T}$ dari tahun sebelumnya atau meningkat sebesar 127\% dari tahun 2015, kemudian dalam Peraturan Presiden Republik Indonesia no. 97 tahun 2016 tentang rincian Anggaran Pendapatan dan Belanja Negara (APBN) tahun anggaran 2017, rincian dana desa menurut Kabupaten/ Kota menyebutkan total nasional dana desa sebesar 60,00 T atau meningkat sebesar $27 \%$ dari tahun sebelumnya.

Kemudian alokasi masing-masing wilayah khususnya provinsi Banten pada tahun 2015 jika dibandingkan dari Dana secara nasional, Provinsi Banten mendapatkan bagian sekitar $1 \%$ atau lebih tepatnya $0.97 \%$, namun pada tahun 2016 secara Nasional bagian Provinsi Banten sebesar 1.68\% meningkat dari tahun sebelumnya hingga tahun 2017 secara Nasional bagian Provinsi Banten sebesar 1.68\% sama dari tahun 2016 tidak ada peningkatan alokasi dana desa untuk provinsi Banten.

Data diatas menggambarkan bahwa dari tahun ke tahun alokasi dana desa secara nasional meningkat dan berdampak bagi provinsi daerah di Indonesia, khusus untuk Banten yang mendapatkan alokasi dana desa terletak di Kabupaten Lebak, Pandeglang, Serang dan Kabupaten Tangerang. Jika diperhatikan daerah Kabupaten yang masih banyak jumlah masyarakat miskinnya, berdasarkan data BPS Provinsi Banten Pada Tahun 2015 terdapat 690,67 ribu penduduk miskin di Provinsi Banten $(5,75 \%)$, meningkat dari tahun 2014 yang sebanyak 649,19 ribu (5,51\%), (BPS Provinsi Banten, 2016).

Tabel Alokasi Dana Desa Nasional

\begin{tabular}{|c|c|c|}
\hline Tahun & Jumlah Dana (Rp) & Trend \\
\hline 2015 & $20.770 .000 .000 .000,-$ & - \\
\hline 2016 & $47.110 .000 .000 .000,-$ & $127 \%$ \\
\hline 2017 & $60.000 .000 .000 .000,-$ & $27 \%$ \\
\hline
\end{tabular}

Sumber: Direktorat Jenderal Anggaran

Kementerian Keuangan Republik Indonesia, diolah 
Tabel Alokasi Dana Desa Provinsi Banten

\begin{tabular}{|c|c|c|}
\hline Tahun & Jumlah & Trend \\
\hline 2015 & 200.985 .513 .850 & - \\
\hline 2016 & 791.252 .019 .000 & $294 \%$ \\
\hline 2017 & 1.009 .506 .961 .000 & $28 \%$ \\
\hline
\end{tabular}

Sumber: Direktorat Jenderal Anggaran

Kementerian Keuangan Republik Indonesia, diolah

Dengan peningkatan dana desa dari tahun ke tahun khususnya di Provinsi Banten, dapat dioptimalkan terutama pengoptimalan ekonomi desa berbasis ekonomi kreatif sehingga Provinsi Banten dapat menanggulangi permasalahan yang ada dan dapat meningkatkan potensi ekonomi yang dimiliki.

Dana Desa yang dialokasikan ke seluruh desa di Indonesia yang mencapai hampir 75.000 desa dan berdasarkan pada Peraturan Menteri Desa, Pembangunan Desa Tertinggal dan Transmigrasi Nomor 4 Tahun 2015 tentang Pendirian, Pengurusan dan Pengelolaan dan Pembubaran Badan Usaha Milik Desa dan Nomor 5 Tahun 2015 tentang Penetapan Prioritas Penggunaan Dana Desa. Dimana beberapa point utama adalah Pemberdayaan Masyarakat Desa adalah upaya mengembangkan kemandirian dan kesejahteraan masyarakat dengan meningkatkan pengetahuan, sikap, keterampilan, perilaku, kemampuan, kesadaran, serta memanfaatkan sumber daya melalui penetapan kebijakan, program, kegiatan, dan pendampingan yang sesuai dengan esensi masalah dan prioritas kebutuhan masyarakat Desa.

Saat ini populasi penduduk dengan usia produktif lebih banyak daripada jumlah lapangan kerja yang tersedia. Hal ini memicu khususnya para pemuda untuk menciptakan peluangnya sendiri dengan membuka bisnis. Sebagian besar tergolong sebagai pelaku usaha sektor industri Usaha Mikro, Kecil dan Menengah (UMKM). Pada tahun 2014 ada sekitar 57,9 juta pelaku UMKM di Indonesia, angka meningkat dibandingkan dengan tahun sebelumnya tahun 2013 sekitar 57.8 juta pelaku UMKM bahkan pada tahun 2015 jumlah UMKM di Indonesia meningkat 59.2 juta dengan kontribusi PDB sebesar 61.41\% dan Tenaga Kerja sebanyak 96.71\% (Kemenkop UKM RI, 2015).

Peranan UMKM dipandang sebagai katup penyelamat dalam proses pemulihan ekonomi nasional baik dalam mendorong laju pertumbuhan ekonomi maupun dalam penyerapan tenaga kerja. Penguatan UMKM merupakan bagian dari langkah pemerintah untuk mempercepat langkah industrialiasi. Sebab, UMKM telah terbukti mampu bertahan di tengah krisis ekonomi, menyerap tenaga kerja serta berperan strategis mendukung ketersediaan pangan nasional. Namun, dari banyaknya jumlah UMKM di Indonesia masih ada beberapa permasalahan yang dihadapi oleh UMKM, berdasarkan data Badan Pusat Statistik beberapa faktor yang menyebabkan Industri Mikro Kecil (IMK) sulit berkembang dapat dilihat pada grafik 1. 
Grafik 1. Persentase Jenis Kesulitan Utama yang

Dialami Perusahaan/Usaha IMK 2015

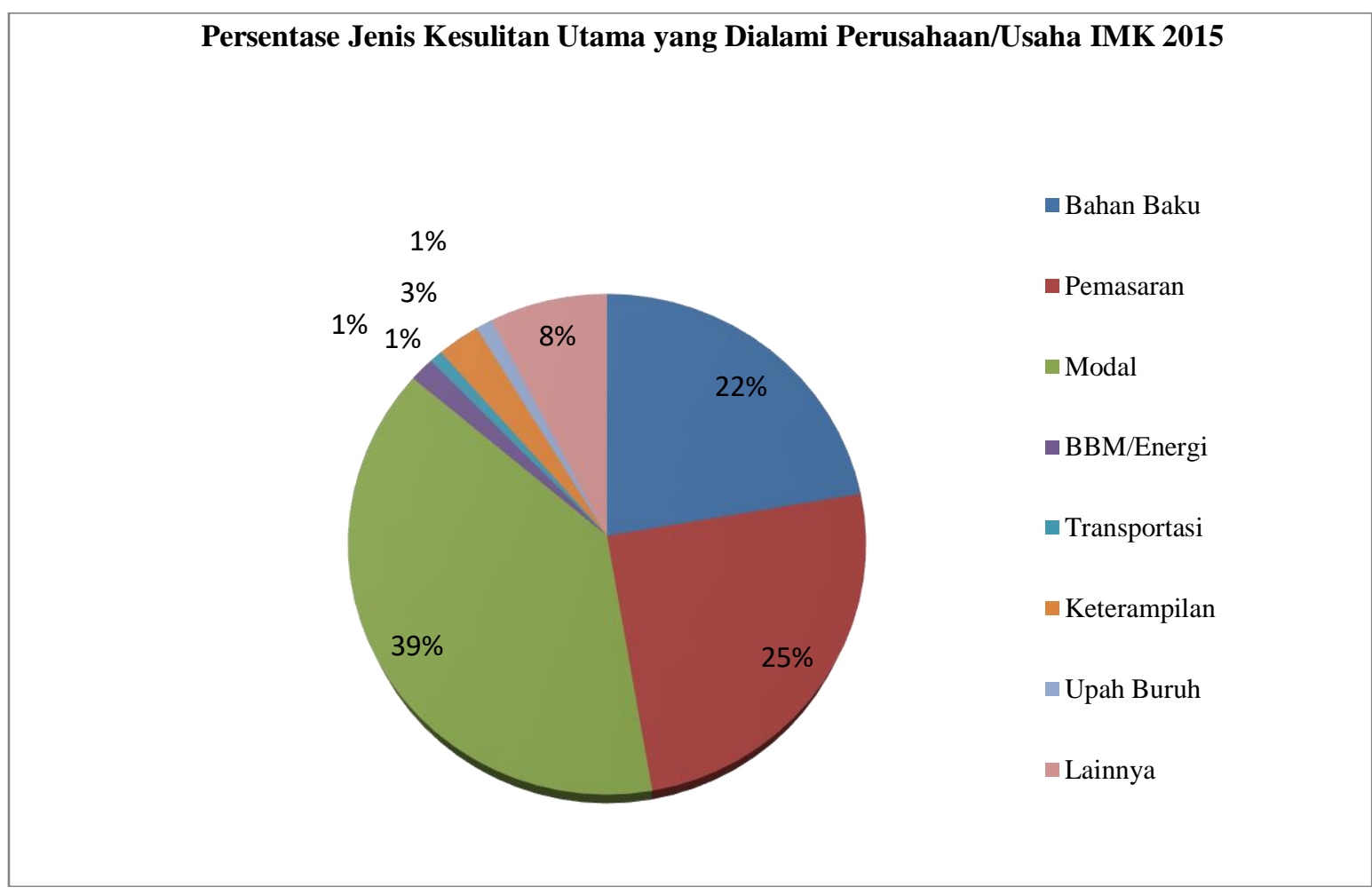

Sumber: Data Diolah (Badan Pusat Statistik, 2015)

Berdasarkan data diatas terlihat bahwa permasalahan utama yang dihadapi oleh Industri Mikro dan Kecil (IMK) adalah Modal dan Pemasaran. Kesulitan utama IMK pada permodalan sebesar $38.84 \%$. Selanjutnya pemasaran yakni $25 \%$ disusul oleh kesulitan bahan baku $22.29 \%$. Kesulitan akan bahan bakar minyak juga terjadi sebesar $1.6 \%$ dan disusul lagi oleh kesulitan keterampilan 0,85\% Upah buruh juga menjadi kendala dalam pengembangan IMK yakni sebesar 1.04\% dan kesulitan lain-lainnya sebesar 7.63\%. Namun, menurut Kementeria Koperasi dan UKM disampaikan oleh Sekretaris Menteri Koperasi dan UKM Tahun 2017 permasalahan UMKM adalah faktor Permodalan atau Pembiayaan, Pemasaran, Manajemen dan Teknlogi serta Kelembagaan masih menjadi permasalahan yang dominan dihadapi oleh Usaha Mikro dan Kecil. Permasalahan ini harus diselesaikan, agar tidak menjadi permasalahan yang berkepanjangan maka diperlukan satu terobosoan. Bentuk terobosan yang dilakukan adalah dengan adanya Alokasi Dana Desa (ADD) ke desa-desa diseluruh Indonesia, sehingga dapat terbentuk adanya BUMDes (Badan Usaha Milik Desa) yang membawahi atau menaungi UMKM yang ada didesa-desa sehingga kebutuhan UMKM bisa diakomodir, bahkan pada saat peringatan Hari Koperasi Nasional (Harkopnas ke-70) di Makassar, salah satu rekomendasinya adalah menjadikan BUMDes agar berbadan hukum Koperasi.

BUMDes yang ada dan tersebar di Indonesia, khususnya pengembangan di Provinsi Banten, dimana Usaha yang dijalankan berbasis Digital. Berdasarkan latar belakang diatas maka, penelitian ini berjudul Pengembangan Ekonomi Kreatif Desa Melalui Badan Usaha Milik Desa (BUMDes) Berbasis UMKM Digital. 


\section{B. Tujuan Penelitian}

Berdasarkan pemodelan ekonomi (economic modelling) yang akan dibuat untuk penelitian ini, berharap penelitian ini akan memberikan masukan guna peningkatan daya saing dan kualitas UKM dalam rangka pembuatan UKM Digital sehinga bertujuan untuk menggandakan tingkat penetrasi broadband dan meningkatkan keterlibatan UKM secara digital dapat meningkatkan pertumbuhan ekonomi tahunan Indonesia sebesar $2 \%$ - pertumbuhan tambahan yang diperlukan untuk mencapai target pertumbuhan $7 \%$ untuk menjadi negara berpenghasilan menengah pada tahun 2025. Saat ini, UKM di Indonesia dipastikan siap untuk memetik keuntungan dari transformasi digital. UKM telah memanfaatkan teknologi dasar untuk mencapai tujuan yang sama. Kebijakan pemerintah memainkan peran penting dalam mempercepat pemanfaatan ekonomi digital - terutama melalui peningkatan akses broadband dan melalui peningkatan koordinasi program-program pemerintah yang sudah ada, fasilitas pembayaran, akses terhadap investasi, dan memfasilitasi akses terhadap piranti digital baru yang lebih terjangkau.

Dengan semakin banyaknya usaha kecil dan menengah (UKM) yang terlibat dalam ekonomi digital melalui pita lebar (broadband), bisnis elektronik (e-commerce), media sosial, teknologi awan (cloud), dan platform telepon seluler/ponsel (mobile platforms), UKM dapat bertumbuh lebih cepat dari segi pendapatan dan penyediaan lapangan kerja, serta menjadi lebih inovatif dan lebih kompetitif untuk menghadapi Masyarakat Ekonomi ASEAN (MEA).

\section{Batasan Penulisan}

Penelitian ini hanya bersifat deskrispi (menggambarkan) dalam bentuk permodelan sistem kelembagaan Badan Usaha Milik Desa (BUMDes) yang dikembangkan oleh perangkat Desa dari Alokasi Dana Desa (ADD) untuk pengotimalan ekonomi berbasis Usaha Mikro, Kecil dan Menengah (UMKM) berbasis Digital.

\section{Landasan Teori}

\section{A. Teori UMKM}

\section{Definisi UMKM}

Beberapa lembaga atau instansi bahkan undang-undang (UU) memberikan definisi Usaha Mikro Kecil Menengah (UMKM). Menurut Badan Pusat Statistik (BPS) memberikan definisi bahwa UMKM berdasarkan kualitas tenaga kerja, yaitu untuk usaha kecil memiliki jumlah tenaga kerja lima sampai dengan 19 orang, sedang usaha menengah memiliki tenaga kerja 20 sampai dengan 99 orang.

Pada tanggal 4 Juli 2008 ditetapkan UU No 20 Tahun 2008 pasal 1 tentang Usaha Mikro Kecil Menengah (UMKM) dibagi menjadi tiga bagian, yaitu:

a. Usaha Mikro adalah usaha produktif miliki orang perorangan dan/atau badan usaha perorangan yang memenuhi kriteria Usaha Mikro sebagaimana diatur dalam Undang-Undang ini.

b. Usaha Kecil adalah usaha ekonomi produktif yang berdiri sendiri, yang dilakukan oleh orang perorangan atau badan usaha yang bukan merupakan anak perusahaan atau bukan cabang perusahaaan yang dimiliki, dikuasai, atau menjadi bagian baik langsung maupun tidak langsung dari Usaha Menengah, atau Usaha Besar yang memenuhi kriteria Usaha Kecil sebagaimana dimaksud dalam Undang-Undang ini.

c. Usaha Menengah adalah usaha ekonomi produktif yang berdiri sendiri, yang dilakukan oleh orang perorangan atau badan usaha yang bukan merupakan 
anak perusahaan atau cabang perusahaan yang dimiliki, dikuasai, atau menjadi bagian baik maupun tidak langsung dengan Usaha Kecil atau Usaha Besar dengan jumlah kekayaan bersih atau hasil penjualan tahunan sebagaimana diatur dalam Undang-Undang ini.

Berdasarkan pengertian diatas maka dapat disimpulkan bahwa Usaha Mikro, Kecil dan Menengah adalah usaha yang berbeda kriterianya dari segi aset dan omset untuk usaha mikro dikategorikan usaha paling kecil dan biasanya hanya dimiliki oleh perorangan dengan beberapa karyawan saja.

2. Kriteria UMKM

Adapun yang menjadi kriteria kekayaan bersih atau hasil penjualan tahunan serta kepemilikan pada undang-undang No. 20 Tahun 2008 pasal 6 adalah sebagai berikut:

a. Kriteria Usaha Mikro adalah sebagai berikut:

1) Memiliki kekayaan bersih paling banyak Rp50.000.000,00 (lima puluh juta rupiah) tidak termasuk tanah dan bangunan tempat usaha atau

2) Memiliki hasil penjualan tahunan paling banyak Rp.300.000.000,00 (tiga ratus juta rupiah)

b. Kriteria Usaha Kecil adalah sebagai berikut:

1) Memiliki kekayaan bersih lebih dari Rp50.000.000,00 (lima puluh juta rupiah) sampai dengan paling banyak Rp500.000.000,00 (lima ratus juta rupiah) tidak termasuk tanah dan bangunan tempat usaha, atau

2) Memiliki hasil penjualan tahunan lebih dari Rp300.000.000,00 (tiga ratus juta rupiah) sampai dengan paling banyak Rp2.500.000.000,00 (dua miliyar lima ratus juta rupiah)

c. Kriteria Usaha Menengah adalah sebagai berikut:

1) Memiliki kekayaan bersih lebih dari Rp500.000.000,00 (lima ratus juta rupiah) sampai dengan paling banyak Rp10.000.000.000,00 (sepuluh miliyar rupiah) tidak termasuk tanah dan bangunan tempat usaha, atau

2) Memiliki hasil penjualan tahunan lebih dari Rp2.500.000.000,00 (dua miliyar lima ratus juta rupiah) sampai dengan paling banyak Rp50.000.000.000,00 (lima puluh miliyar rupiah)

2. Desa dan BUMDes

a. Definisi Desa

Desa menurut UU nomor 32 tahun 2004 tentang Pemerintahan Daerah mengartikan Desa sebagai berikut :

“Desa atau yang disebut nama lain, selanjutnya disebut desa, adalah kesatuan masyarakat hukum yang memiliki batas-batas wilayah yang berwenang untuk mengatur dan mengurus kepentingan masyarakat setempat, berdasarkan asal-usul dan adat istiadat setempat yang diakui dan dihormati dalam sistem Pemerintah Negara Kesatuan Republik Indonesia (UU No. 32 tahun 2004 tentang Pemerintahan Daerah pasal 1 ayat 12). 
Tabel

Desa Lama versus Desa Baru

\begin{tabular}{|c|c|c|}
\hline Keterangan & Desa Lama & Desa Baru \\
\hline Payung Hukum & $\begin{array}{l}\text { UU No } 23 / 2004 \text { dan PP } \\
\text { No } 72 / 2005\end{array}$ & UU No 6/2014 \\
\hline Asas Utama & $\begin{array}{l}\text { Desentralisasi - } \\
\text { residualitas }\end{array}$ & Rekognisi - Subsidiaritas \\
\hline Kedudukan & $\begin{array}{l}\text { Sebagai organisasi } \\
\text { pemerintah yang berada } \\
\text { dalam sistem } \\
\text { pemerintahan } \\
\text { kabupaten/kota (local } \\
\text { state government) }\end{array}$ & $\begin{array}{l}\text { Sebagai pemerintahan } \\
\text { masyarakat, hybrid antara } \\
\text { self governing community } \\
\text { dan local self government }\end{array}$ \\
\hline $\begin{array}{l}\text { Posisi dan Peran } \\
\text { Kabupaten/Kota }\end{array}$ & $\begin{array}{l}\text { Kabupaten/kota } \\
\text { mempunyai } \\
\text { kewenangan yang besar } \\
\text { dan luas dalam } \\
\text { mengatur dan } \\
\text { mengurus desa }\end{array}$ & $\begin{array}{l}\text { Kabupaten/kota } \\
\text { mempunyai kewenangan } \\
\text { yang terbatas dan } \\
\text { strategi dalam mengatur } \\
\text { dan mengurus desa; } \\
\text { termasuk mengatur dan } \\
\text { mengurus bidang urusan } \\
\text { desa yang tidak perlu } \\
\text { ditangani langsung oleh } \\
\text { pusat }\end{array}$ \\
\hline $\begin{array}{l}\text { Delivery Kewenangan } \\
\text { dan Program }\end{array}$ & Target & Mandat \\
\hline Politik Tempat & $\begin{array}{l}\text { Lokasi : Desa sebagai } \\
\text { lokasi proyek dari atas }\end{array}$ & $\begin{array}{l}\text { Arena : Desa sebagai } \\
\text { arena bagi orang desa } \\
\text { untuk menyelenggarakan } \\
\text { pemerintahan, } \\
\text { pembangunan, } \\
\text { pemberdayaan dan } \\
\text { kemasyarakatan }\end{array}$ \\
\hline $\begin{array}{l}\text { Posisi dalam } \\
\text { Pembangunan }\end{array}$ & Objek & Subjek \\
\hline Model Pembangunan & $\begin{array}{l}\text { Government driven } \\
\text { development atau } \\
\text { community driven } \\
\text { development }\end{array}$ & $\begin{array}{l}\text { Village driven } \\
\text { development }\end{array}$ \\
\hline $\begin{array}{l}\text { Pendekatan dan } \\
\text { Tindakan }\end{array}$ & $\begin{array}{l}\text { Imposisi dan Mutilasi } \\
\text { Sektoral }\end{array}$ & $\begin{array}{l}\text { Fasilitasi, Emansipasi } \\
\text { dan Konsolidasi }\end{array}$ \\
\hline
\end{tabular}

Sumber : Sutoro Eko dkk, Desa Membangun Indonesia, Yogyakarta :FPPD, 2014

b. Definisi Badan Usaha Milik Desa

Badan Usaha Milik Desa, yang selanjutnya disebut BUM Desa, berdasarkan UU No 6 Tahun 2014 BUM Desa adalah badan usaha yang seluruh atau sebagian besar modalnya dimiliki oleh Desa melalui penyertaan secara 
langsung yang berasal dari kekayaan Desa yang dipisahkan guna mengelola aset, jasa pelayanan, dan usaha lainnya untuk sebesarbesarnya kesejahteraan masyarakat Desa.

BUM Desa dikelola dengan semangat kekeluargaan dan kegotongroyongan serta dapat menjalankan usaha di bidang ekonomi dan/atau pelayanan umum sesuai dengan ketentuan peraturan perundang-undangan. Dan dalam pendirian BUM Desa disepakati melalu Musyawarah Desa

Hasil usaha BUM Desa dimanfaatkan untuk: a. pengembangan usaha; dan b. Pembangunan Desa, pemberdayaan masyarakat Desa, dan pemberian bantuan untuk masyarakat miskin melalui hibah, bantuan sosial, dan kegiatan dana bergulir yang ditetapkan dalam Anggaran Pendapatan dan Belanja Desa.

3. Digitalisasi Ekonomi

Berdasarkan Kamus Bahasa Indonesia, digitalisasi adalah proses pemberian atau pemakaian sistem digital. Dalam hal digitalisasi ekonomi atau usaha, maka diklasifikasikan menjadi :

Pertama, bisnins offline adalah usaha yang tidak memiliki akses terhadap broadband, tidak memiliki komputer atau smartphone dan tidak memiliki website.

Kedua, Bisnins online dasar adalah bisnis yang memiliki akses broadband dan alat digital seperti komputer dan smartphone, dan memiliki website. Namun, bisnis tersebut tidak terlibat dalam media sosial (kecuali email) dan tidak memiliki kemampuan $e$ commerce untuk pemesanan atau pembayaran.

Ketiga, Bisnis online menengah adalah bisnis yang memiliki konektivitas digital dan juga secara aktif terlibat dalam media sosial dengan mengintegrasikan situs mereka dengan media sosial, live chat atau ulasan konsumen. Bisnis ini belum memiliki kapabilitas e-commerce sepenuhnya.

Keempat, Online lanjutan memiliki konektivitas, integrasi jejaring sosial dan kapabilitas e-commerce. Kami mencatat bahwa diatas tingkatan ini, terdapat banyak cara lain dimana bisnis dapat memanfaatkan teknologi digital tetapi hal tersebut bukan merupakan fokus utama penelitian ini.

\section{METODOLOGI}

\section{A. Jenis Penelitian}

Jenis penelitian ini merupakan penelitian kualitatif dengan pendekatan deskriptif komparatif. Penelitian deskriptif adalah penelitian yang dilakukan untuk menggambarkan data yang dikumpulkan berupa kata-kata, gambar, dan bukan angkaangka. Hal itu disebabkan oleh adanya penerapan metode kualitatif (Moleong, 2010). Pada penelitian ini peneliti mendeskripsikan pengelolaan desa melalui keuangan yang ada dari Anggaran Negara melalui Alokasi Dana Desa (ADD) dalam rangka pembentukan Badan Usaha Milik Desa (BUMDes) untuk mengoptimalkan potensi ekonomi yang ada di Desa tersebut dan dikembangkan agar menjadi badan usaha yang mapan dengan penerapan teknologi berupa Financial Technology dan Market Place.

\section{B. Jenis dan Teknik Pengumpulan Data}

Jenis Data yang akan digunakan dalam penelitian ini bersumber dari data primer, dimana data primer merupakan data yang didapat dari sumber pertama baik dari individu atau perseorangan seperti hasil dari wawancara yang biasa dilakukan oleh peneliti (Umar, 2013). Dalam penelitian ini teknik pengumpulan data primer melalui wawancara secara langsung terkait pengoptimalan desa. Dalam penelitian ini sumber data yang didapat dari hasil wawancara aparatur desa, dan masyarakat desa.

Jenis data berikutnya adalah data sekunder merupakan data primer yang telah diolah lebih lanjut dan disajikan baik oleh pihak pengumpul data primer atau oleh pihak lain misalnya dalam bentuk data, tabel-tabel atau diagram-diagram (Umar, 2013). 
Dalam penelitian ini dengan mempelajari berbagai literatur-literatur seperti peraturan, buku, jurnal maupun artikel ilmiah yang terkait dengan model pengembangan desa dalam penelitian ini.

\section{Kerangka Pemikiran}

Berdasarkan landasan teori, penelitian ini menggambarkan kerangka pemikiran sebagai berikut :

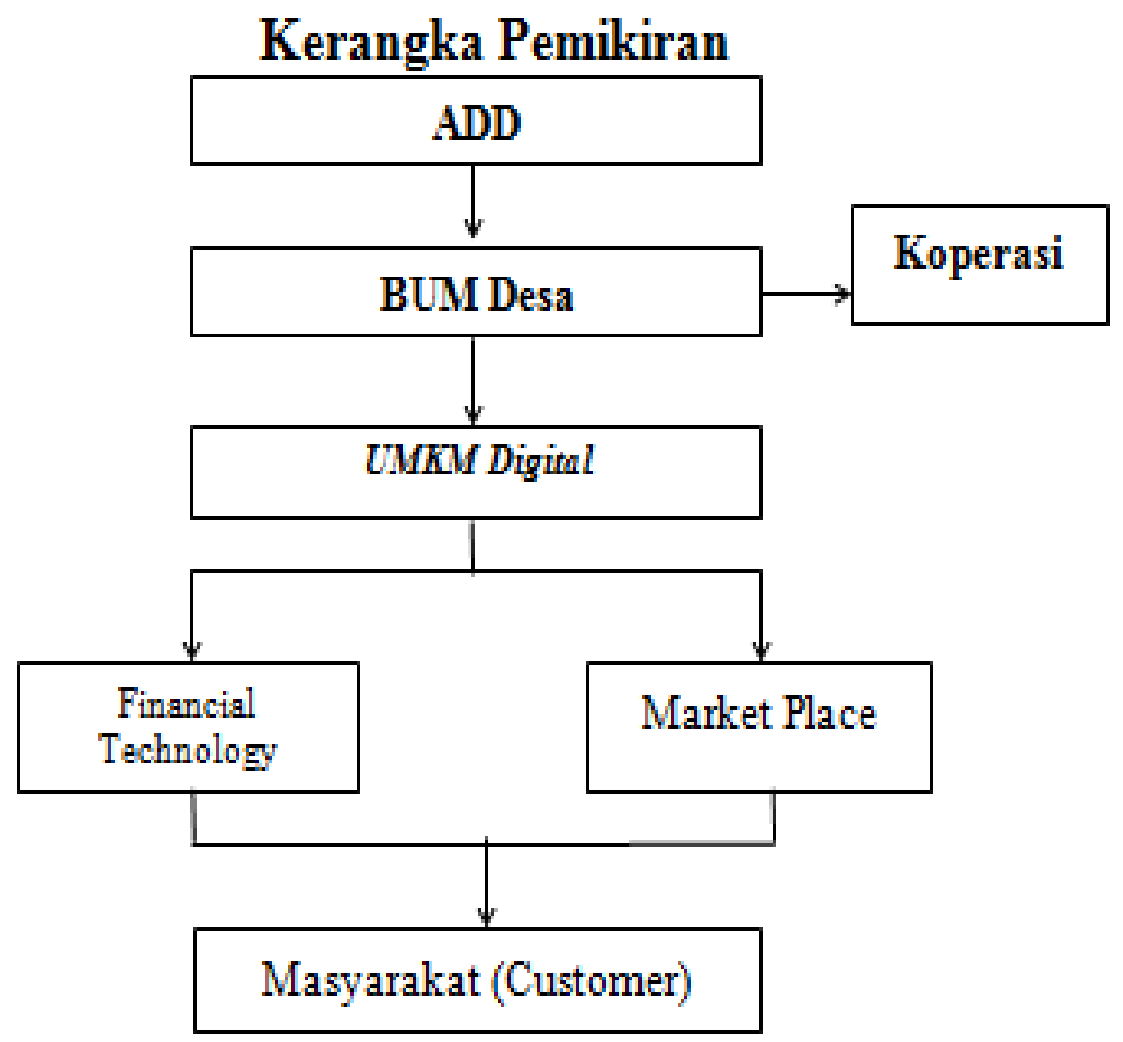

Sumber: (Diolah penulis, 2017)

\section{ANALISA DAN PEMBAHASAN}

\section{A. Mekanisme Pembentukan BUM Desa}

Pemerintah desa menyusun perencanaan pembangunan desa sesuai dengan kewenangannya dengan mengacu pada perencanaan pembangunan kabupaten dan kota. Rencana pembangunan desa disusun untuk menjamin kesesuaian dan konsistensi antara perencanaan, penganggaran, pelaksanaan, dan pengawasan (Sujarweni, 2015).

Perencanaan desa yang telah ditetapkan dalam RPJM Desa yang kemudian dijabarkan dalam RKP Desa menjadi dasar untuk menyusun perencanaan pengelolaan keuangan desa yang berupa APBDes (Anggaran Pendapatan dan Belanja Desa). APBDes merupakan rencana keuangan tahunan pemerintah desa yang memuat sumber pendapatan, alokasi belanja dan pembiayaan. Sehingga secara garis besar perencanaan Desa, Ambil saja satu Desa di Wilayah Kabupaten yang ada di Provinsi Banten mulai dari RPJM Desa sampai terbentuknya APBDes dapat digambarkan dengan alur sebagai berikut: 


\section{Contoh Desa Bantarsari}

Perencanaan Pengelolaan Keuangan Desa Bantarsari

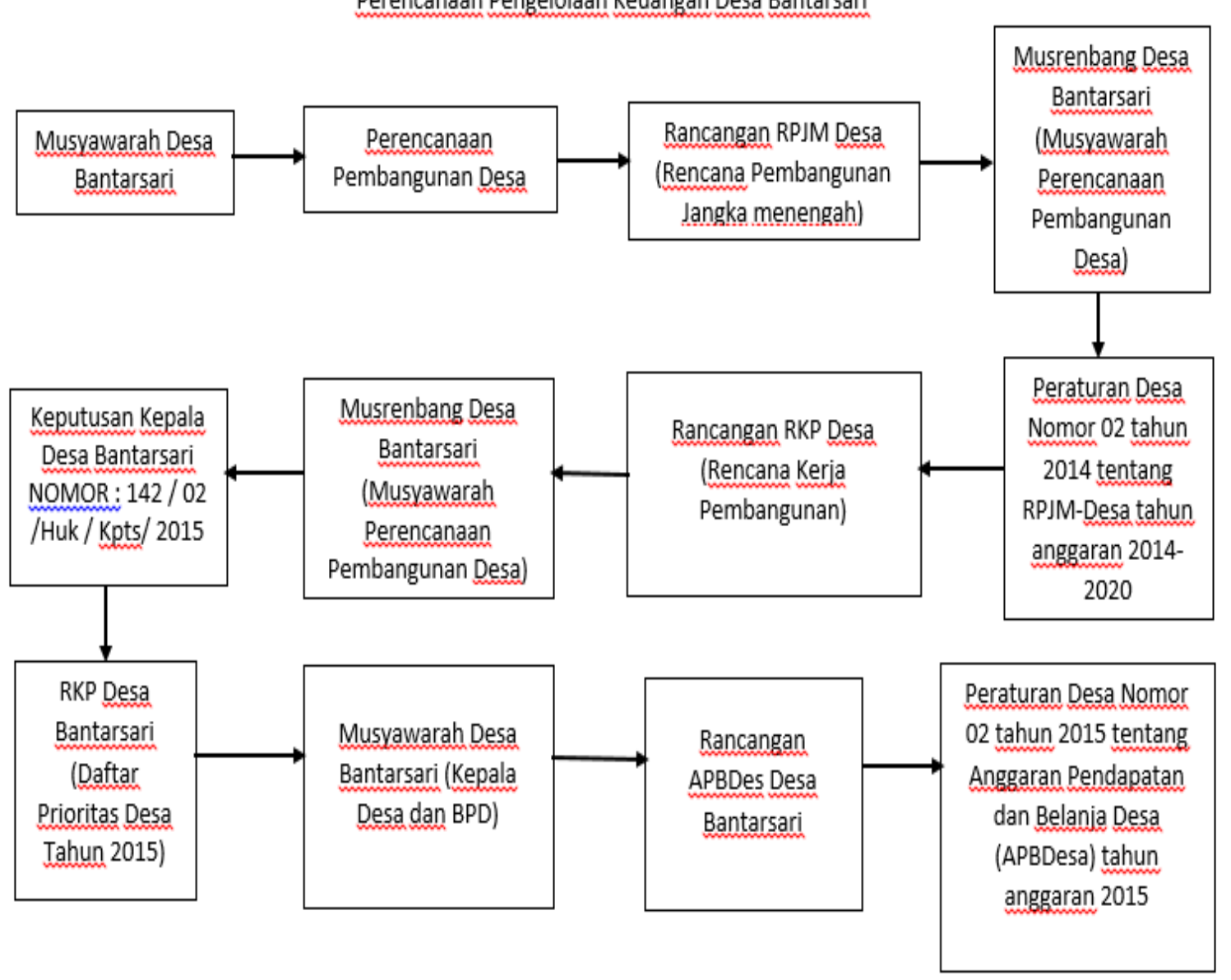

Sumber : data diolah

Saat pelaksanaan Musrenbang, seluruh lapisan masyarakat yang memiliki kepentingan turut menyepakati RKP Desa, disinilah peran penting untuk Pembentukan BUMDes harus disepakati pada saat Musrenbang. Badan Usaha Milik Desa adalah Lembaga Usaha Desa yang dikelola oleh Masyarakat dan Pemerintah Desa dalam upaya memperkuat perekonomian desa dan dibentuk berdasarkan kebutuhan dan potensi desa.

Ciri Utama BUMDes dengan Lembaga Ekonomi Komersil lainya adalah sebagai berikut :

1. Badan Usaha ini dimiliki oleh desa dan dikelola bersama

2. Modal bersumber dari desa sebesar $51 \%$ dan dari masyarakat sebesar $49 \%$ melalui penyertaan modal (Saham atau andil)

3. Operasinya menggunakan falsafah bisnis yang berakar dari budaya lokal

4. Bidang usaha yang dijalankan berdasarkan pada potensi dan informasi pasar

5. Keuntungan yang di peroleh di tunjukan untuk meningkatkan kesejahteraan anggota (Penyerta Modal) dan masyarakat melalui kebijakan desa

6. Difasilitasi oleh Pemerintah Provinsi, Pemerintah Kabupaten dan Pemerintah Desa.

7. Operasional dikontrol secara bersama (oleh BPD, Pemerintah Desa dan Anggota)

BUMDes sebagai suatu lembaga ekonomi modal usahanya dibangun atas inisiatif masyarakat dan menganut asas mandiri. Ini berarti pemenuhan modal usaha BUMDes harus bersumber dari masyarakat. Meskipun demikian, tidak menutup 
kemungkinan BUMDes dapat mengajukan pinjaman modal kepada pihak luar, seperti dari Pemerintah Desa atau pihak lain, bahkan melalui pihak ketiga.

\section{B. Tahapan BUMDes Menuju Koperasi}

Idealnya BUMDes berbadan hukum Koperasi, namun perlu dilakukan dengan tahapan sebagai berikut :

1. Inisiator pembentukan BUMDes berbadan hukum koperasi mempunyai peran penting dalam kegiatan ekonomi masyarakat desa serta potensi pengembangannya, artinya Koperasi merupakan usaha yang sudah jelas badan hukumnya.

2. Koperasi berikut tata kelolanya baiknya buat pertemuan lanjutan dengan mengundang beberapa orang yang mengerti atau praktisi koperasi ( koperasi yang bener lho ya, bukan rentenir baju koperasi alias koperasi abal2).

3. Kalau diperlukan sesi pendidikan dasar perkoperasian untuk para pendiri agar pemahamannya lebih mantap akan lebih baik.

4. Lalu, kalau sudah dapat dipahami maka baiknya diskusikan dengan Kepala Desa dan juga tokoh2 masyarakat desa secara lebih luas untuk bahas pembentukan Tim Pendiri, siapkan draft AD ART, Rencana Program Kerja, Anggaran Pendapatan dan biaya, struktur organisasi dan calon2 pengurusnya, dll.

5. Kalau ide telah disetujui maka selenggarakan pembahasan pembentukan BUMDes Koperasi dalam Musyawarah Desa (Musdes). Dalam putusan Musdes ini baiknya sudah memuat : berapa besar yang akan dihibahkan oleh Pemdes untuk modal awal koperasi dan bagaimana langkah sosialisasinya kepada warga secara lebih luas.

6. Setelah BUMDes koperasi berjalan maka barulah diurus badan hukum koperasinya.

7. Pengurusan badan hukum dan syarat-syaratnya sebaiknya ditanyakan kepada Notaris yang telah memiliki nomor induk notaris koperasi dan diserahkan kepada mereka seluruh berkas-berkasnya (standardnya : AD-ART, program kerja, anggaran pendapatan dan belanja, struktur kepengurusan, rekomendasi dinas koperasi dan ukm, dll( kalau untuk sinpan pinjam biasanya ada banyak tambahannya)

8. Perlu diketahui bahwa pengurusan badan hukum (diluar NPWP, TDP, SIUP, dsb itu gratis karena persatuan notaris indonesia sudah MoU dengan Kemenkop akan direimburs dari APBN sebanyak 2.5 juta).

BUMDes itu milik pemdes dan masyarakat, jadi kepemilikkan pemerintah itu hanya untuk jamin bahwa kepentingan publik tetap terjaga. Keanggotaan koperasi itu khan sukarela dan terbuka ini adalah representasi demokrasi dan terbuka itu artinya tanpa batasan semua warga desa bisa jadi anggotanya tanpa diskriminasi apapun juga.

\section{Kerjasama Potensi Ekonomi berdasarkan Sektor}

1. Kerjasama Sektor Ekonomi

Sektor-sekor Ekonomi memiliki peranan besar karena saling terkait untuk dapat memecahkan permasalahan yang ada. Beberapa potensi pengembangan ekonomi diwilayah Banten, diantaranya : Pertama, perekonomian masyarakat pertanian, peternakan dan perkebunan, sektor pertanian menjadi sektor yang memiliki kontribusi besar seiring dengan program pemerintah dalam pertanian ada program Padi, Jagung dan Kedelai (Pajale), dalam peternakan ada program Sapi Betina Wajib Bunting dan perkebunan. Kedua, perekonomian masyarakat pesisir, sektor industri dan jasa menjadi sektor yang memiliki kontribusi besar dalam pengembangan usaha produktif masyarakat. Ketiga, kelestarian lingkungan juga tidak lepas dari peran serta dan keterlibatan sektor industri dimana biasanya limbah industri dibuang ke perairan.

Perlu Infrastruktur pendukung juga menjadi hal penting untuk dapat mengembangkan wilayah dan menjaga kelestarian lingkungan. Untuk itu, kerjasama 
lintas sektor sangat perlu diperhatikan karena masing-masing sektor memiliki kepentingannya sendiri-sendiri. Masing-masing sektor harus saling mendukung. Peran BUMDes dalam hal ini sangat besar agar terjadi sinergi yang baik dalam pengembangan setiap sektor, sehingga akan terbentuk lembaga bisnis yang optimal dengan menciptakan keuntungan yang maksimal.

2. Kerjasama Antar wilayah

Kawasan di Provinsi Banten terbagi menjadi dua kawasan yakni pesisir dan daratan. Berkaitan dengan hal ini, maka wilayah yang termasuk dalam suatu kawasan (adanya homogenitas baik secara ekologis maupun ekonomis) haruslah saling bekerjasama untuk meminimalisir permasalahan yang terjadi. Kerjasama antar wilayah dapat digalang melalui pembentukan forum kerjasama atau forum komunikasi antar pemerintah desa yang memiliki kawasan pesisir dan laut dengan kawasan daratan tentang pemanfaatan sumberdaya lokal sesuai dengan semangat otonomi daerah.

3. Kerjasama Antar Aktor (stakeholders)

Upaya pengurangan kesenjangan sektoral dan daerah jelas memerlukan strategi khusus bagi penanganan secara komprehensif dan berkesinambungan. Untuk itu, diperlukan adanya kebijakan dari Pemerintah Desa untuk menjembatani persoalan kemiskinan dan kesenjangan sektoral dan daerah tersebut, melalui mekanisme kerjasama antar aktor (stakehokders) yang melibatkan unsur-unsur masyarakat (kelompok nelayan), pihak swasta (Private Sector), dan pemerintah (Government). Terobosan pemikiran bagi upaya percepatan pembangunan dan pengembangan ekonomi lokal yang melibatkan partispasi masyarakat dalam proses dan pelaksanaan pengelolaannya. Upaya penanggulangan kemiskinan dan kesenjangan sektoral dan daerah tersebut yang berintikan suatu paradigma baru, dimana inisiatif pembangunan desa tidak lagi digulirkan dari pusat, namun merupakan inisiatif lokal (desa) untuk memutuskan langkah-langkah yang terbaik dalam mengimplementasikan rencana pengelolaan kawasan dan rencana aksi yang sesuai dengan kebutuhan dan kapasitas yang dimiliki. Dengan adanya BUMDes yang berbadan hukum Koperasi diharapkan mampu mengembangkan potensi ekonomi yang ada di desa wilayah Provinsi Banten.

\section{Penerapan Model UMKM Digital dari BUMDesa}

BUMDes bisa dikatakan sebagai Koperasi Primer yang terdapat dimasingmasing desa dalam suatu Kabupaten, sebelumnya sudah dijabarkan pembentukan BUMDes dalam bentuk hukum koperasi dan diharapkan bentukan ini bisa meluas keseluruhan desa-desa yang ada di Kabupaten khususnya Kabupaten di Wilayah Provinsi Banten. Jika BUMDes primer terbentuk dimasing-masing Desa, maka akan mudah untuk mensinergikan pembentukan BUMDes yang sekunder berbasis Kabupaten. 


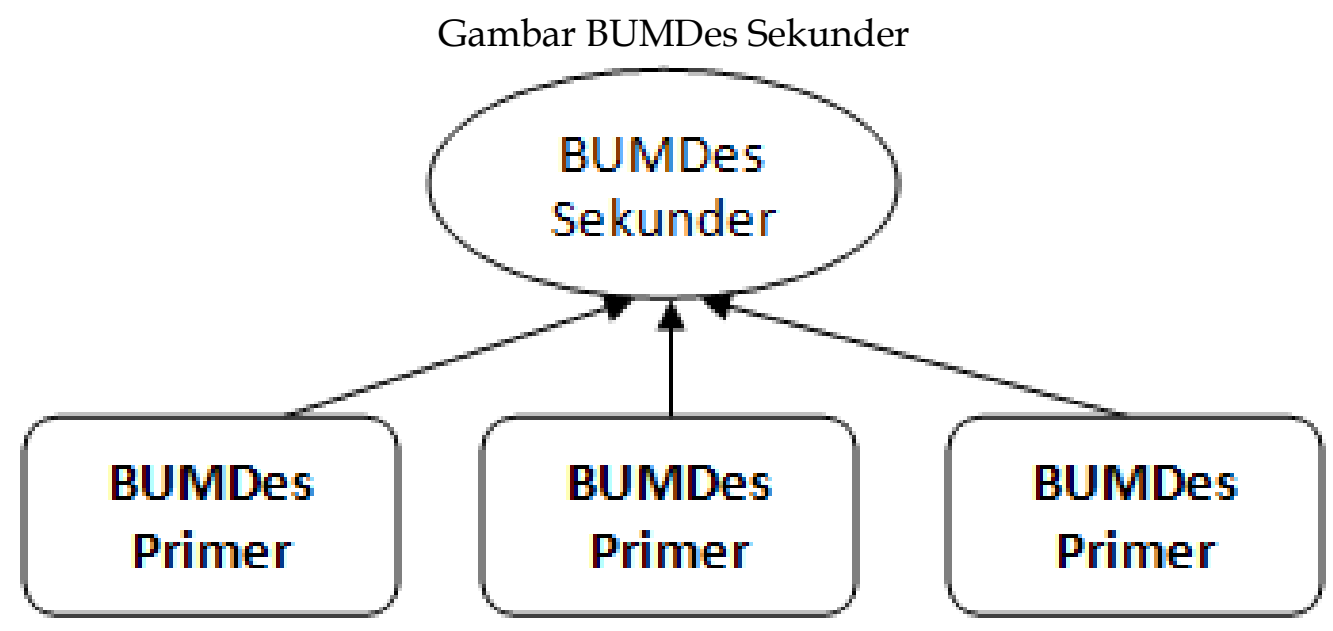

Sumber : data diolah

Dengan pola BUMDes atau Koperasi sekunder pada dasarnya seluruh kegiatan yang diperlukan untuk mendukung pengembangan BUMDes atau koperasi primer dilakukan oleh koperasi sekunder secara berjenjang dari tingkat daerah, wilayah, nasional dan bahkan internasional. Fungsi-fungsi kegiatan pemusatan pengembangan koperasi diantaranya : Pertama, bidang pembiayaan meliputi bidang keuangan yang terdiri atas penghimpunan dan penyaluran dana melalui silang pinjam (interlanding) dan pengelolaan resiko. Kedua, bidang non jasa keuangan yang terdiri atas konsultasi manajemen simpan pinjam, pendidikan dan pelatihan, akuntansi dan audit, pengadaan sarana usaha dan audit. Ketiga, Pengembangan Usaha lainnya seperti pengembangan Unit Bisnis seperti Jasa Transportasi, Komunikasi dan lainnya. Keungulan BUMDes atau koperasi sekunder sebagai model pemusatan pengembangan koperasi adalah : (1) Struktur dan sistemnya telah tersedia, baik secara lokal, nasional maupun internasional sehingga tinggal masalah penerapan. (2) Penerapan BUMDes atau koperasi sekunder sebagai model pemusatan lebih menjamin penerapan nilai-nilai dan prinsip-prinsip koperasi, sehingga lebih menjamin terwujudnya cita-cita koperasi yaitu peningkatan kesejahteraan dan kemandirian ekonomi anggota koperasi.

Neraca BUMDes Sekunder

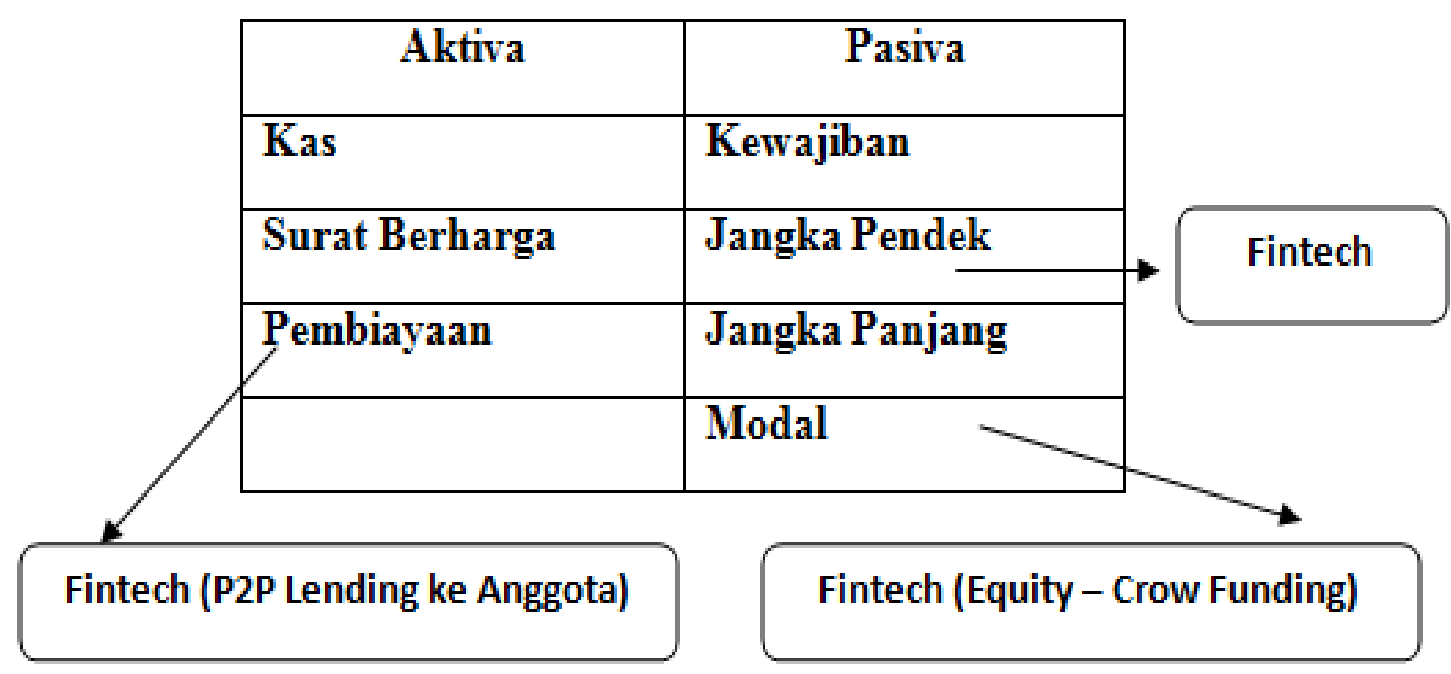

Sumber : data diolah 


\section{Neraca UKMI}

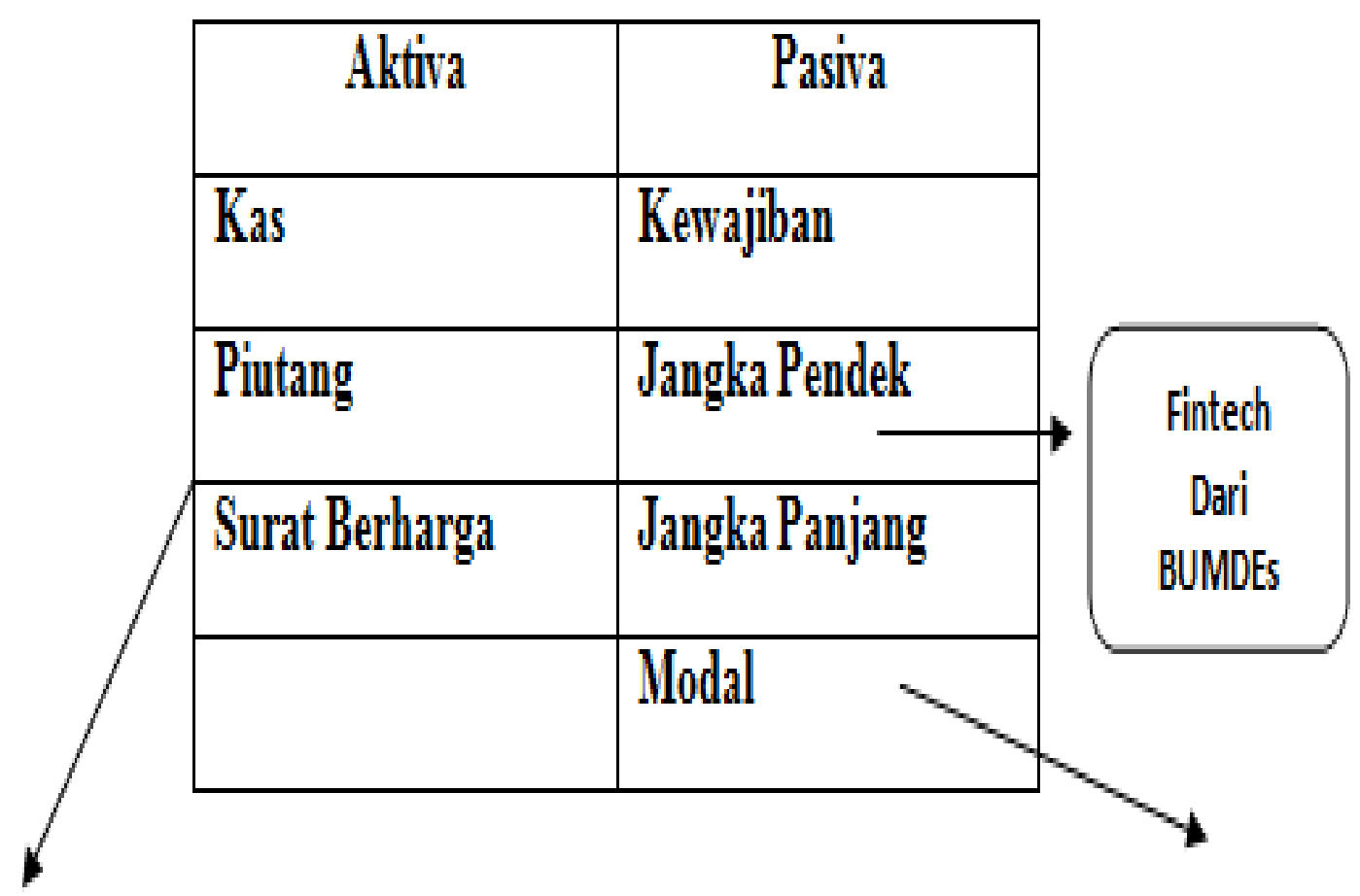

\section{Fintech (Equity-Crow Funding)}

\section{Fintech (Equity-Crow Funding)}

Sumber : data diolah

Ke depan harapan bahwa BUMDes atau Koperasi Sekunder mempunyai peran yang lebih dalam mengembangkan lembaga yakni berbasis Teknologi, yang harus dikembangkan adalah berbasisi Financial Technologi atau dikenal dengan Fintech.

Berdasarkan gambar neraca tersebut pengembangan Fintech untuk BUMDes atau Koperasi Sekunder berdasarkan dua pendekatan yakni, pertama dari sisi passiva pendekatan dilakukan lebih kepada pihak eksternal seperti Lembaga atau Individu dengan pendekatan Financial Technology lembaga BUMDes atau Koperasi Sekunder bisa berpeluang mendapatkan suntikan dana dari Lembaga atau Individu. Pendekatan kedua, dari sisi aktica model Financial Technologi diterapkan kepada para anggota tau BUMDes Primer dan kemudian BUMDes Premier melanjutkan atau mengucurkan dari yang bersumber dari induk kepada sektor riil dan Usaha Mikro dan Kecil (UMK). Karena langsung ke sektor riil maka mitigasi risiko diperlukan, agar perlindungan dana pengguna sangat perlu diperhatikan terhadap potensi kehilangan maupun penurunan kemampuan financial baik akibat penyalahgunaan, penipuan maupun force majeure.

Jika merujuk pada gambar di atas, pendekatan yang dilakukan bahwa dari segi passive bisa permodalan dan pembiayaan, dari segi pembiayaan, Financial Technology yang dibangun berasal dari dana BUMDes atau Koperasi Primer ke Usaha Mikro dan Kecil (UMK) pemberian dana dalam bentuk 
pembiayaan bahkan UMK bisa mendapat permodalan dari crowdfunding yang dikembangkan oleh UMK. Dan jika usaha ini berjalan lancar dan menghasilkan laba maka yang harus dilakukan UMK adalah mengalokasikan asset usaha ke asset yang produktif seperti tabungan, surat berharga atau model investasi lainnya.

\section{E. Pengembangan dengan Market Place}

Pengembangan selanjutnya jika, Usaha Mikro dan Kecil ini berkembang masing-masing desa, maka diperlukan konsep pemasaran yang lebih canggih lagi. Perkembangan teknologi tidak hanya mengubah cara berkomunikasi masyarakat namun juga metode perdagangannya. Saat ini, banyak bermunculan e-commerce yang berguna untuk jadi tempat jual berli barang secara online yang bisa digunakan oleh UMK. Bentuk saat ini yang cocok adalah Market Place, dimana UMK bisa memanfaatkan teknologi dengan memasang produk mereka, spesifikasi barang dan harga serta isi barang tersebut dalam suatu web atau model sejenisnya, manfaat bagi UMK adalah memberikan efisiensi biaya sehingga harga barang yang diproduksi atau dihasilkan UMK menjadi murah serta manfaat lain memasarkan produk lebih luas dari sebelumnya.

\section{KESIMPULAN}

Satu bentuk terobosan dalam mengembangkan program Alokasi Dana Desa dengan bentuk Badan Usaha Milik Desa (BUMDes) yang berbadan hukum koperasi baik ruang lingkup primer dari masing-masing desa-desa dan lingkup sekunder dari Kabupaten. Pengembangan berikutnya berbasis teknologi berupa financial technologi dan market place bagi UMK.

\section{DAFTAR PUSTAKA}

Abidin, M. Z. (2015). Tinjauan Atas Pelaksanaan Keuangan Desa Dalam Mendukung Kebijakan Dana Desa (Study of Implementation of Village Finance to Support Fund Village Policy). Jurnal Ekonomi dan Kebijakan Publik, 61-76.

BPKP. (2015). Kawal Keuangan Desa. Vol. XXII/Edisi HUT Ke-70 RI 2015

BPKP. (2017). Pengawalan Keuangan Desa dengan Aplikasi SISKEUDES. Retrieved Januari 8, 2017, from http://www.bpkp.go.id/sakd/konten/2448/leaflet-simdadesa.bpkp

BPS. (2014, Februari 18). Persentase Penduduk Daerah Perkotaan menurut Provinsi, 20102035. Retrieved Januari 8, 2017, from https://www.bps.go.id/linkTabelStatis/view/id/1276

BPS. (2015, Oktober 7). Perkiraan Penduduk Beberapa Negara. Retrieved Januari 8, 2017, from https://www.bps.go.id/linkTableDinamis/view/id/960

BPS. (2016, Agustus 18). Persentase Penduduk Miskin Menurut Provinsi 2013-2016.

Retrieved Januari 8, 2017, from

https://www.bps.go.id/linkTableDinamis/view/id/1219

Direktorat Jenderal Anggaran Kementerian Keuangan Republik Indonesia. (n.d.). http://www.anggaran.depkeu.go.id/dja/edef-peraturan-jenis

list.asp?hal=2Ejenis=4Ekategori=1. Retrieved Januari 12, 2017， from http://www.anggaran.depkeu.go.id/dja/default.asp.

Direktorat Penelitian dan Pengembangan. (2015). Laporan Kajian Sistem Pengelolaan Keuangan Desa: Alokasi Dana Desa dan Dana Desa. KPK.

Eko, Sutoro dkk (2014), Desa Membangun Indonesia, Yogyakarta: FPPD

Fajri, R., Setyowati, E., \& Siswidiyanto. (n.d.). Akuntabilitas Pemerintahan Desa Pada Pengelolaan Alokasi Dana Desa (ADD) (Studi pada Kantor Desa Ketindan, 
Kecamatan Lawang, Kabupaten Malang). Jurnal Administrasi Publik (JAP), 10991104.

Hidayat, Sedarmayanti , \& Syarifudin. (2011). Metodologi Penelitian. Bandung: CV. Mandar Maju.

Kemendagri. (2015, Maret 2). Retrieved from http://www.kemendagri.go.id/basisdata/2015/03/02/ permendagri-ri-no56-tahun-2015-tentang-kode-dan-datawilayah-administrasi-pemerintahan

Kementerian Keuangan. (2014). Kebijakan Hubungan Keuangan Pusat dan Daerah (HKPD) Dalam Rangka Peningkatan Kualitas Pelayanan Publik. Jakarta: Direktorat Jenderal Perimbangan Keuangan.

Lestari, A. K., Atmadja, A. T., \& Adiputra, M. P. (2014). Membedah Akuntabilitas Praktik Pengelolaan Keuangan Desa Pakraman Kubutambahan, Kecamatan Kubutambah, Kabupaten Buleleng, Provinsi Bali (Sebuah Studi Interpretif pada Organisasi Publik Non Pemerintahan). e-journal S1 Ak Universitas Pendidikan Ganesha Vol: 2 No:1.

Moleong, L. J. (2010). Metodologi Penelitian kualitatif. Bandung: PT Remaja Rosdakarya. Peraturan Menteri Dalam Negeri Nomor 113 Tahun 2014 tentang Pengelolaan Keuangan Desa.

Peraturan Menteri Dalam Negeri Nomor 114 Tahun 2014 tentang Pedoman Pembangunan Desa.

Rahmawati, H. I. (2015). Analisis Kesiapan Desa Dalam Implementasi Penerapan UU Nomor 6 Tahun 2014 Tentang Desa (Studi pada Delapan Desa di Kabupaten Sleman). ISSN 2407-9189, 305-313.

Republik Indonesia. (2014). Nota Keuangan dan Anggaran Pendapatan dan Belanja Negara Tahun Anggaran 2014.

Sujarweni, V. W. (2015). Akuntansi Desa: Panduan Tata Kelola Keuangan Desa. Yogyakarta: Pustaka Baru Press.

Undang-undang Nomor 6 Tahun 2014. (15 Januari 2014). Desa. Lembaran Negara Republik Indonesia Tahun 2014 Nomor 7, Jakarta. 